\title{
ISOLATION AND CHARACTERIZATION OF INHIBITORS OF ANIMAL CELL-FREE PROTEIN SYNTHESIS FROM BARLEY SEEDS
}

by

\author{
KATSUHIKO ASANO, BIRTE SVENSSON and FLEMMING M. POULSEN
}

Department of Chemistry, Carlsberg Laboratory, Gamle Carlsberg Vej 10, DK-2500 Copenhagen Valby

Keywords: Translation inhibitor, single chain polypeptides, basic proteins

Three inhibitors of animal cell-free protein synthesis were isolated from barley seeds by ammonium sulfate fractionation, CM-cellulose chromatography and gel filtration on Bio-Gel P-60. The three inhibitors were all single chain, basic proteins with molecular weights about 31,000 and with very similar amino acid compositions. In the rabbit reticulocyte lysate system, they inhibited in vitro translation to $50 \%$ at concentrations between 15 and 25 $\mathrm{ng} \cdot \mathrm{ml}^{-1}$, while in the wheat germ system, their effect was very weak. The three translation inhibitors showed no detectable ribonuclease activity neither on ribosomal RNA from rabbit liver nor on homopolynucleotides.

\section{INTRODUCTION}

Proteins that inhibit animal cell-free protein synthesis were recently described to be present in barley seeds $(4,28)$. These proteins, however, have not been characterized in detail. Similar proteins having inhibitory activities on the translation are found in a wide variety of plants $(4,12,13,26,33)$. Several of these proteins are highly toxic to intact cells, whereas others only inhibit the cell free systems. The toxic proteins such as ricin from castor bean (Ricinus communis) (26) are known to consist of two different polypeptide chains called the $A$ chain and the $B$ chain. The A chain inhibits the translation, but requires the $B$ chain to enter the intact cells (26). On the other hand, the non-toxic inhibitors such as pokeweed antiviral protein (PAP) from Phytolacca americana $(2,18)$ and tritin from wheat (Triticum aestirum) $(28,29)$ are both single chain polypeptides analogous to the A chain of the toxic proteins. The non-toxic inhibitors isolated from different plants so far are all basic proteins with molecular weights of about 30,000 .

The present study describes the isolation and some structural and functional properties of three translation inhibitors from barley seeds. The three inhibitors appear to be closely related molecules and resemble the other non-toxic translation inhibitors in some physical and chemical properties.

Abbreviations: DTT $=$ dithiothreitol; EDTA $=$ ethylenediamine tetraacetic acid, disodium salt; $F P L C=$ fast protein liquid chromatography; Hepes $=\mathrm{N}$-2-hydroxyethylpiperazine- $\mathrm{N}$-2-ethanesulfonic acid; $\mathrm{PAP}=$ pokeweed antiviral protein; PTH- = phenylthiohydantoin-; SDS = sodium dodecylsulfate; Tris = 2-amino-2-hydroxymethylpropane1,3-diol 


\section{MATERIALS AND METHODS}

\subsection{Materials}

The high-lysine mutant barley, Risø 1508 , grown at the Carlsberg Research Farm was used as a source for the translation inhibitor. Bomi, the mother variety of Risø 1508 , was also obtained from the Carlsberg Research Farm. Barley hordein messenger RNA was prepared from immature barley endosperm as described (3, 16). Wheat germ extract (3) was a gift from Dr. ANDERS BRANDT, Department of Physiology, Carlsberg Laboratory. Ribosomal RNA was in principle prepared from rabbit liver as previously described $(8,36)$ using $20 \mathrm{~mm}$-Hepes $\mathrm{pH}$ 7.6 containing $0.2 \mathrm{M}$-sucrose, $100 \mathrm{~mm}$-potassium acetate, $50 \mathrm{~mm}$-magnesium acetate, 2 mM-DTT and 1\% Triton X-100 for extraction buffer and $20 \mathrm{mM}-\mathrm{Hepes} \mathrm{pH} 7.6$ containing 1.75 M-sucrose, $100 \mathrm{~mm}$-potassium acetate, $5 \mathrm{mM}$ magnesium acetate and 2 mM-DTT for ultracentrifugation buffer. Antiserum against translation inhibitor II was a custom preparation from Dakopatts, Copenhagen, Denmark.

The sources of chemicals used in this work were as follows: CM-cellulose, CM-52 from Whatman, Maidstone, U.K.; Bio-Gels P-60 and P-100 from Bio-Rad, Richmond, CA; protein standards for SDS-polyacrylamide gel electrophoresis, gel filtration and isoelectric focusing from Pharmacia Fine Chemicals, Uppsala, Sweden; carrier ampholytes from LKB, Bromma, Sweden; lysate of rabbit reticulocyte (messenger RNA dependent) and $\mathrm{L}-\left[{ }^{35} \mathrm{~S}\right]$ methionine from Amersham International, Amersham, U.K.; $\operatorname{poly}(A), \operatorname{poly}(G), \operatorname{poly}(C)$ and $\operatorname{poly}(\mathrm{U})$ from Sigma Chemical Co., St. Louis, MO. All other chemicals were of analytical reagent grade.

\subsection{Extraction and purification of translation inhibitors}

Barley whole seeds ( $12 \mathrm{~kg}$ ) were ground and extracted at $4{ }^{\circ} \mathrm{C}$ for 4.5 hours with 2501 of 0.1 $\mathrm{M}-\mathrm{NaCl}$ containing $2.5 \mathrm{mM}$-ascorbic acid and 2.5 mm-EDTA. During the extraction, $\mathrm{pH}$ was maintained at 6.3 with $\mathrm{NaOH}$. The extract was left at $4{ }^{\circ} \mathrm{C}$ overnight and the supernatant was concentrated to 201 on a DDS 600 ultrafilter (Danish Sugar Refineries, Nakskov, Denmark) and subsequently fractionated at 50 to $70 \%$ saturation of $\left(\mathrm{NH}_{4}\right)_{2} \mathrm{SO}_{4}$. The precipitate obtained was redissolved in a minimum volume of water and dialyzed against water. After removing insoluble material by centrifugation, the supernatant (approx. 21 ) was adjusted to pH 7.0 with $\mathrm{NaOH}$ and applied to a $\mathrm{CM}$-cellulose column $(5 \times 47 \mathrm{~cm})$, preequilibrated with 25 mM-sodium phosphate $\mathrm{pH} 7.0$ containing 0.05 $\mathrm{M}-\mathrm{NaCl}$. After washing the column with the buffer to remove unadsorbed material, it was eluted with an 81 linear gradient of 0.05 to 0.2 $\mathrm{M}-\mathrm{NaCl}$ in the same buffer at a flow rate of 180 $\mathrm{ml} \cdot \mathrm{h}^{-1}$. Fractions having inhibitory activity on in vitro translation were pooled and rechromatographed on a CM-cellulose column $(5 \times 11$ $\mathrm{cm}$ ) in a similar manner as above, and then purified batchwise on a Bio-Gel P-60 column (5 $\times 84 \mathrm{~cm}$ ) with $50 \mathrm{~mm}$-sodium phosphate $\mathrm{pH} 6.5$ containing $5 \mathrm{mM}^{-\mathrm{NaN}_{3}}$ as an elution buffer. The fractions containing translation inhibitors were pooled, dialyzed against water and subsequently lyophilized.

\subsection{Analytical procedures}

Inhibition of in vitro translation was determined either in the rabbit reticulocyte lysate system or in the wheat germ system. In the former system, $15 \mu$ l of rabbit reticulocyte lysate was incubated with $1 \mu \mathrm{l}$ of $L-\left[{ }^{35} S\right]$ methionine (10 $\mu \mathrm{Ci}$ ), $2 \mu \mathrm{l}$ of barley hordein messenger RNA and $2 \mu \mathrm{l}$ of sample solution at $30^{\circ} \mathrm{C}$ for $\mathrm{l}$ hour. In the latter system, the wheat germ extract was incubated with barley hordein messenger RNA and the protein sample in $25 \mu$ of the assay mixture as described (3). After incubation, a $2 \mu \mathrm{l}$ aliquot was spotted on a filter paper and boiled in $10 \%$ trichloroacetic acid for 10 minutes. The incorporated $\mathrm{L}-\left[{ }^{35} \mathrm{~S}\right]$ methionine was measured as the hot acid-insoluble radioactivity in a Beckman LS 3155T liquid scintillation counter. The inhibitory activity was determined as $\%$ inhibition by the decrease in the incorporation of $L-\left[{ }^{33} S\right]$ methionine relative to an inhibitor free control.

The ribonuclease activity on rabbit liver ribosomal RNA was assayed essentially as described by ENDO et al. (8) for $\alpha$-sarcin. Ribosomal RNA (2.0 $\mathrm{A}_{260}$ units) was incubated with $2 \mu \mathrm{g}$ of protein sample in $30 \mu \mathrm{l}$ of $50 \mathrm{~mm}-\mathrm{Tris}-\mathrm{HCl} \mathrm{pH}$ 7.6 containing $50 \mathrm{~mm}-\mathrm{KCl}$ and $5 \mathrm{~mm}$-EDTA at 
$37^{\circ} \mathrm{C}$ for 15 minutes. After incubation, the RNA was analyzed by electrophoresis on a $1.0 \%$ agarose gel (14). The ribonuclease activity on homopolynucleotides was measured in $100 \mu \mathrm{l}$ of 50 mM-Tris- $\mathrm{HCl} \mathrm{pH} 7.5$ containing $50 \mathrm{mM}-\mathrm{KCl}$, $50 \mu \mathrm{g}$ of homopolynucleotide and $10 \mu \mathrm{g}$ of protein as previously described (21).

The molecular weight was estimated both by gel filtration on a Bio-Gel P-100 column (1.6 $\times$ $85 \mathrm{~cm}$ ) with $50 \mathrm{~mm}$-sodium phosphate $\mathrm{pH} 6.5$ containing $5 \mathrm{mM}^{-\mathrm{NaN}_{3}}$ as an elution buffer and by SDS-polyacrylamide gel electrophoresis (22) on a $16 \%$ polyacrylamide slab gel ( $1 \mathrm{~mm}$ thick) containing $0.1 \%$ SDS. In the latter case, the samples were preincubated at $100{ }^{\circ} \mathrm{C}$ for 5 minutes in a $62.5 \mathrm{mM}-\mathrm{Tris}-\mathrm{HCl} \mathrm{pH} 6.8$ containing $2 \%$ SDS, $5 \%$ mercaptoethanol, $10 \%$ glycerol and $0.001 \%$ p-bromophenol blue.

The homogeneity of the protein preparations was examined by the Pharmacia FPLC system (Pharmacia Fine Chemicals, Uppsala, Sweden) using a prepacked Mono $S$ column $(0.5 \times 5 \mathrm{~cm})$. The column was eluted with a $15 \mathrm{ml}$ linear gradient of 0 to $0.15 \mathrm{M}-\mathrm{NaCl}$ in $25 \mathrm{~mm}$-sodium phosphate $\mathrm{pH} 7.5$ at a flow rate of $1 \mathrm{ml} \cdot \mathrm{min}^{-1}$ and the absorbance at $280 \mathrm{~nm}$ was monitored.

The isoelectric point was determined by isoelectric focusing on a polyacrylamide slab gel $(0.5$ mm thick) containing $1.2 \%$ carrier ampholyte (pH 9 to 11) according to the manufacturers instructions (19).

The immunological cross-reactivity of the three translation inhibitors was examined by double-immunodiffusion in a $1 \%$ agarose gel containing $0.15 \mathrm{M}-\mathrm{NaCl}$.

The contents of translation inhibitors were determined by rocket immunoelectrophoresis (23) in a $1 \%$ agarose gel in Tris-barbiturate $\mathrm{pH}$ 8.6 containing the antiserum against translation inhibitor II $\left(3.9 \mu \mathrm{l} \cdot \mathrm{cm}^{-2}\right)$ using purified translation inhibitors as standards.

The amino acid composition was analyzed on a Durrum D-500 amino acid analyzer. The protein sample was hydrolyzed in $6 \mathrm{M}-\mathrm{HCl}$ in sealed evacuated tubes at $110^{\circ} \mathrm{C}$ for 24,48 and 72 hours. The half-cystine content was measured after performic acid oxidation (15) and also after reduction and 2-pyridylethylation (10,

Table I.

Purification of translation inhibitors from barley seeds

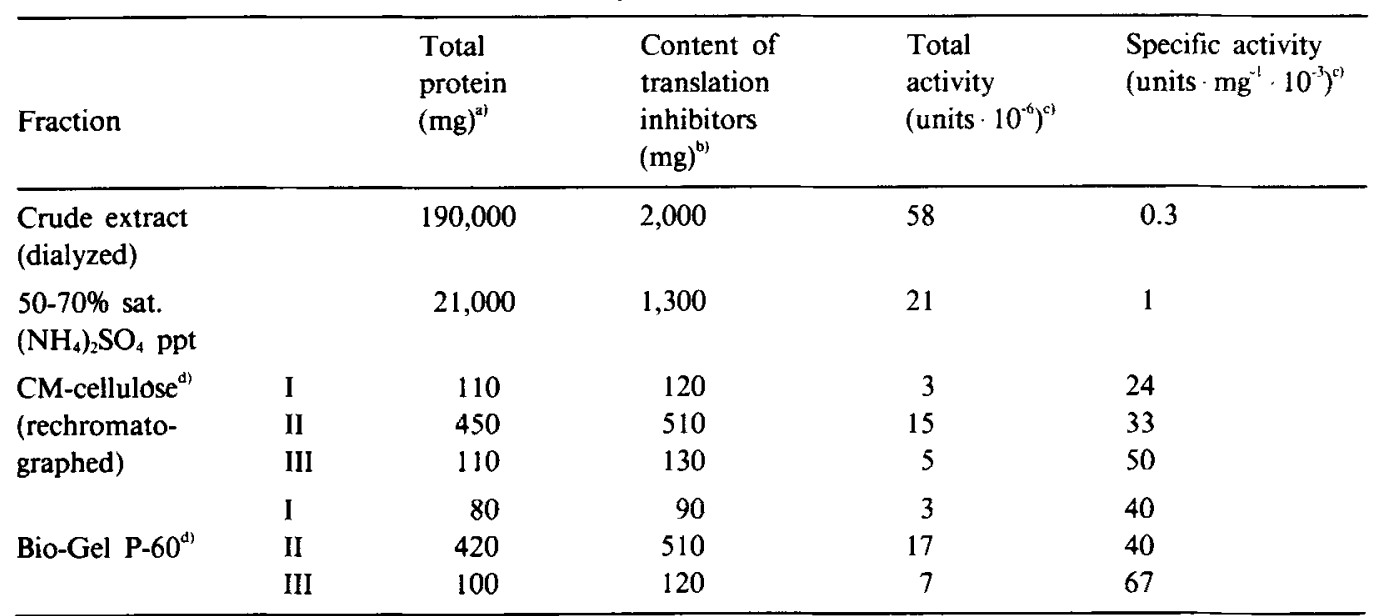

a) Estimated from the UV-absorbance using the $\varepsilon_{280}=3.6 \times 10^{4} \mathrm{M}^{-1} \cdot \mathrm{cm}^{-1}$ for translation inhibitor II, which was calculated from $E_{280}$-measurement and amino acid analyses of solutions of the protein.

b) Determined by rocket immunoelectrophoresis using translation inhibitors I, II and III, respectively, as standards. Translation inhibitor II was used as a standard for the crude extract and the $\left(\mathrm{NH}_{4}\right)_{2} \mathrm{SO}_{4} \mathrm{ppt}$.

c) One unit of activity is defined as the amount of protein that produces $50 \%$ inhibition of the in vitro translation in the rabbit reticulocyte lysate system.

d) Fractions I, II and III correspond to translation inhibitors I, II and III, respectively. 


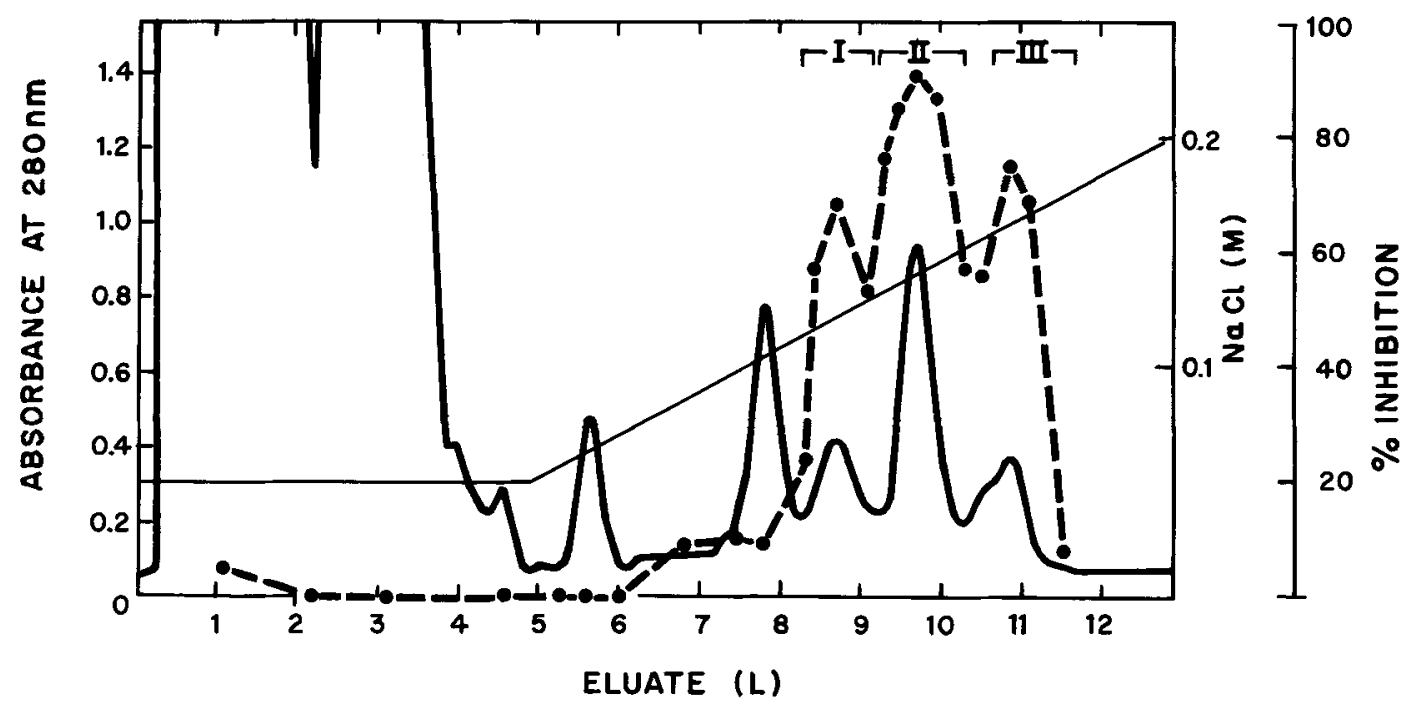

Figure 1. Separation of the three translation inhibitors on CM-cellulose. The dialyzed fraction of $50-70 \%$ saturated $\left(\mathrm{NH}_{4}\right)_{2} \mathrm{SO}_{4}$ precipitate was chromatographed on a CM-cellulose column. The column was first washed with 25 mM-sodium phosphate $\mathrm{pH} 7.0$ containing $0.05 \mathrm{M}-\mathrm{NaCl}$ and then eluted with a linear gradient of 0.05 to $0.2 \mathrm{M}-\mathrm{NaCl}$ in the same buffer (-). The eluate was monitored for the absorbance at $280 \mathrm{~nm}(-)$, and fractions, after 1:500 dilution, were tested for inhibition of in vitro translation in the rabbit reticulocyte lysate system (--@-.). The active fractions indicated by the horizontal bars were pooled.

35). Tryptophan was determined both by second-derivative UV-spectroscopy $(1,31)$ and by amino acid analysis after hydrolysis in $4 \mathrm{M}-\mathrm{me}-$ thanesulfonic acid at $125^{\circ} \mathrm{C}$ for 20 hours (24).

Automated $\mathrm{NH}_{2}$-terminal amino acid sequencing was performed using a Beckman Sequencer $890 \mathrm{C}$ as previously described $(20$, 34).

Total neutral carbohydrate was determined by the phenol sulfuric acid method (6) using glucose as a standard. Aminosugar was determined on the amino acid analyzer after hydrolysis in $4 \mathrm{M}-\mathrm{HCl}$ at $110^{\circ} \mathrm{C}$ for 6 hours, using glucosamine as a standard.

\section{RESULTS AND DISCUSSION}

\subsection{Purification of translation inhibitors}

The results of the purification of the translation inhibitors from $12 \mathrm{~kg}$ barley seeds are summarized in Table I. The three protein fractions having inhibitory activity, in the following called the translation inhibitors I, II and III, were separated on CM-cellulose (Figure 1) and subsequently purified on Bio-Gel P-60. The chromatographic behavior of these three translation inhibitors on CM-cellulose was similar to that of the three forms of tritin, the translation inhibitors from wheat (28). The yields of the three translation inhibitors were about 80,420 and $100 \mathrm{mg}$, respectively, and they constituted about $1 \%$ of the total amount of proteins extracted. The three inhibitors all gave single protein bands in the same position on a SDS-polyacrylamide gel (Figure 2). Furthermore, the analysis by the FPLC of the translation inhibitors II and III showed, for both of them, a single symmetrical peak with distinct retention time, suggesting that they are different and highly pure proteins (Figure 3-II, -III). On the other hand, the translation inhibitor I apparently contained several protein species (Figure 3-I). The inhibitory activity of the three translation inhibitors was almost equal and, on the basis of protein content, 100 to 200 times higher than that of the crude extract.

\subsection{Structural characterization}

The molecular weights of the three translation inhibitors were estimated to be 31,000 by SDSpolyacrylamide gel electrophoresis after reduction (Figure 2) and 33,000 by gel filtration on Bio-Gel P-100. This suggests that the three 


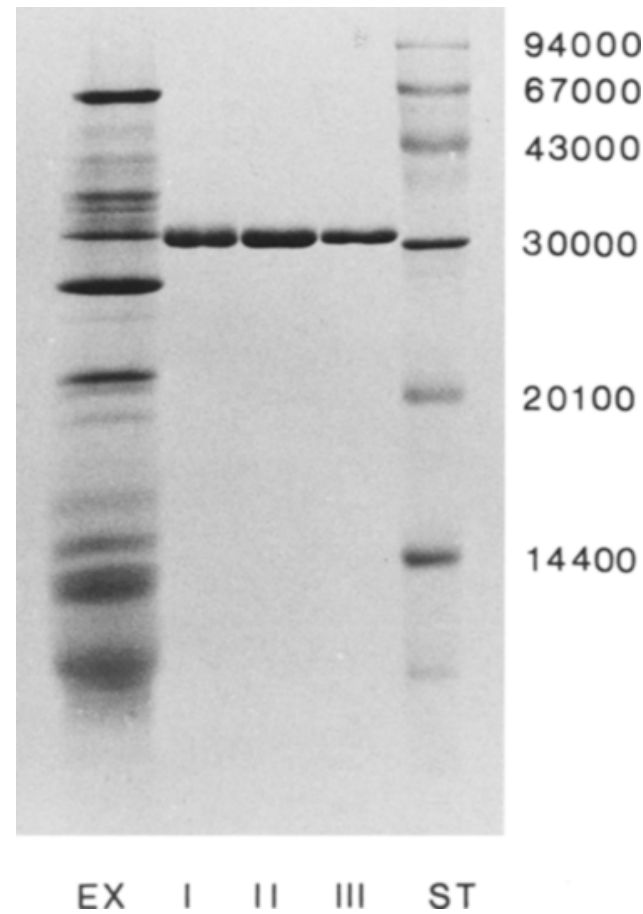

Figure 2. SDS-polyacrylamide gel electrophoresis of the three translation inhibitors. Fifteen micrograms of translation inhibitors I, II and III (I, II and III, respectively) were run on a $16 \%$ SDS-polyacrylamide slab gel with the dialyzed crude extract (EX) and standard proteins (ST, from bottom to top: $\alpha$-lactalbumin, soybean trypsin inhibitor, carbonic anhydrase, ovalbumin, bovine serum albumin and phosphorylase b).

translation inhibitors each consist of a single polypeptide chain, like other non-toxic translation inhibitors, whose molecular weights are also about 30,000 . Neither neutral carbohydrate nor aminosugar were detected in any of the three translation inhibitors.

The three translation inhibitors had very similar amino acid compositions (Table II). They had slightly different isoelectric points around 10 , suggesting that the majority of aspartic and glutamic acid residues measured by amino acid analysis originates from the corresponding amides. Furthermore, the difference in the chromatographic behavior of the three inhibitors on the

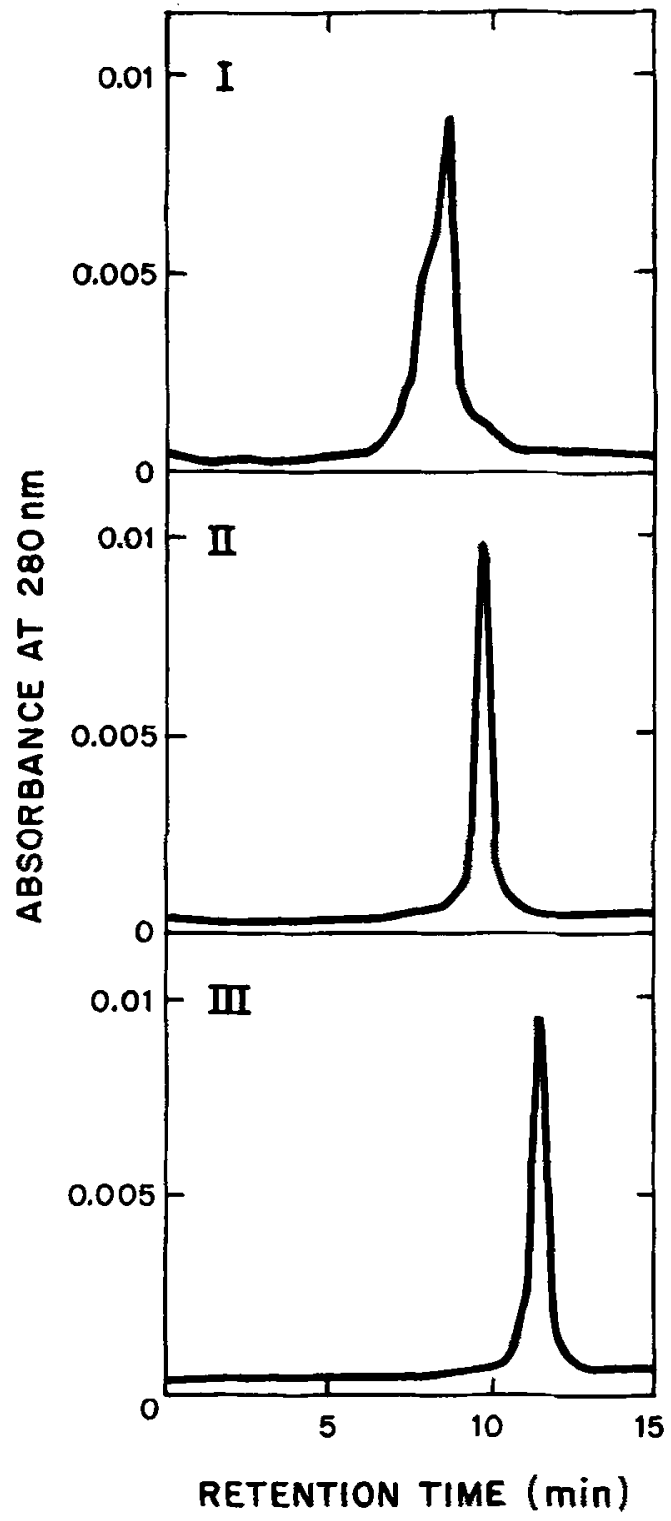

Figure 3. FPLC-elution profiles of the three translation inhibitors. Translation inhibitors I, II and III $(10,5$ and $5 \mu \mathrm{g}$, respectively) were analyzed by FPLC on a Mono S column monitoring the absorbance at $280 \mathrm{~nm}$.

cation exchange resins, CM-cellulose and Mono $\mathrm{S}$, as described in section 3.1. may be due to different extents of deamidation of asparagine and glutamine in the three inhibitors. Comparison of the amino acid compositions of translation inhibitors from plants, including the A chain of toxic proteins, reveals large differences 
Table II

Amino acid compositions of the translation inhibitors

\begin{tabular}{|c|c|c|c|}
\hline \multirow{2}{*}{ Amino acid } & \multicolumn{3}{|c|}{ Residues per molecule } \\
\hline & I & II & III \\
\hline Asx & 24 & 24 & 25 \\
\hline$T_{h r}{ }^{\text {a) }}$ & 23 & 23 & 22 \\
\hline $\operatorname{Ser}^{\mathrm{a}}$ & 17 & 15 & 16 \\
\hline Glx & 24 & 24 & 23 \\
\hline Pro & 19 & 20 & 19 \\
\hline Gly & 27 & 27 & 27 \\
\hline Ala & 37 & 37 & 38 \\
\hline $\mathrm{Val}^{\text {b) }}$ & 22 & 22 & 23 \\
\hline Met & 4 & 4 & 4 \\
\hline $\mathrm{Ile}^{\mathrm{b})}$ & 7 & 8 & 7 \\
\hline Leu & 30 & 30 & 30 \\
\hline Tyr & 4 & 4 & 4 \\
\hline Phe & 12 & 12 & 12 \\
\hline His & 7 & 6 & 5 \\
\hline Lys & 21 & 22 & 22 \\
\hline Arg & 11 & 12 & 12 \\
\hline Cys $^{c)}$ & 0 & 0 & 0 \\
\hline $\operatorname{Trp}^{d \prime}$ & 5 & 4 & 5 \\
\hline Total number of residues & (294) & $(293)$ & $(293)$ \\
\hline
\end{tabular}

a) Extrapolated to zero-time of hydrolysis.

b) Value of 72 hours hydrolysis.

c) Examined by performic acid oxidation (15) and by 2-pyridylethylation $(10,35)$.

d) By second derivative UV-spectroscopy. Values of about $80 \%$ of the listed values were obtained by amino acid analysis after methanesulfonic acid hydrolysis. e) Calculated from the amino acid composition.

$(2,9,11,18,33)$. The amino acid compositions of translation inhibitors from barley were also distinctly different from those of other translation inhibitors.

The $\mathrm{NH}_{2}$-terminal amino acid sequences of the three translation inhibitors were examined by automated Edman degradation. In all cases, however, no PTH-amino acids were detected, suggesting that the $\mathrm{NH}_{2}$-terminal amino acid residues of the three inhibitors were blocked. A blocked $\mathrm{NH}_{2}$-terminus has not been observed for other translation inhibitors $(11,17)$.

The immunological cross-reactivity of the three translation inhibitors was analyzed by double immunodiffusion using antiserum against the translation inhibitor II. The immu-

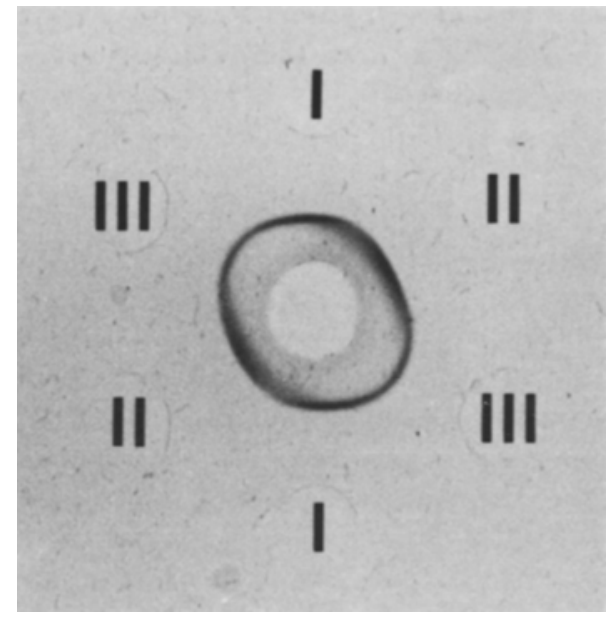

Figure 4. Double immunodiffusion of the three translation inhibitors. The wells contained $39 \mathrm{ng}$ of translation inhibitors I, II and III (I, II and III, respectively). The center well contained $10 \mu \mathrm{l}$ of antiserum against translation inhibitor II.

noprecipitate lines formed between the antiserum and the three inhibitors fused completely, suggesting that the three inhibitors had the same antigenic determinants (Figure 4). The rocket immunoelectrophoresis, however, showed that the antigenicity of the translation inhibitor III was five to ten times lower than those of the translation inhibitors I and II. The rocket immunoelectrophoresis also showed that immunologically identical proteins were abundant in other barley varieties such as Bomi (the mother variety of Risø 1508).

\subsection{Functional characterization}

The translation inhibitors I, II and III inhibited in vitro translation in the rabbit reticulocyte lysate system to $50 \%$ at a concentration of 25,25 and $15 \mathrm{ng} \cdot \mathrm{ml}^{-1}\left(\mathrm{ID}_{\mathrm{s} 0}\right)$, respectively (Figure $5)$. These activities are ten times higher than that of tritin (28), but 20 times lower than that of PAP (2). In the wheat germ system, however, the barley translation inhibitors I, II and III showed much lower activities, i.e. ID $_{s_{0}}$ values were 10 , 150 and $200 \mu \mathrm{g} \cdot \mathrm{ml}^{-1}$, respectively.

It has been suggested that PAP and tritin act catalytically to inactivate eukaryotic ribosomes in cell free systems and they should thus be classified as enzymes $(5,29)$. Furthermore, a 


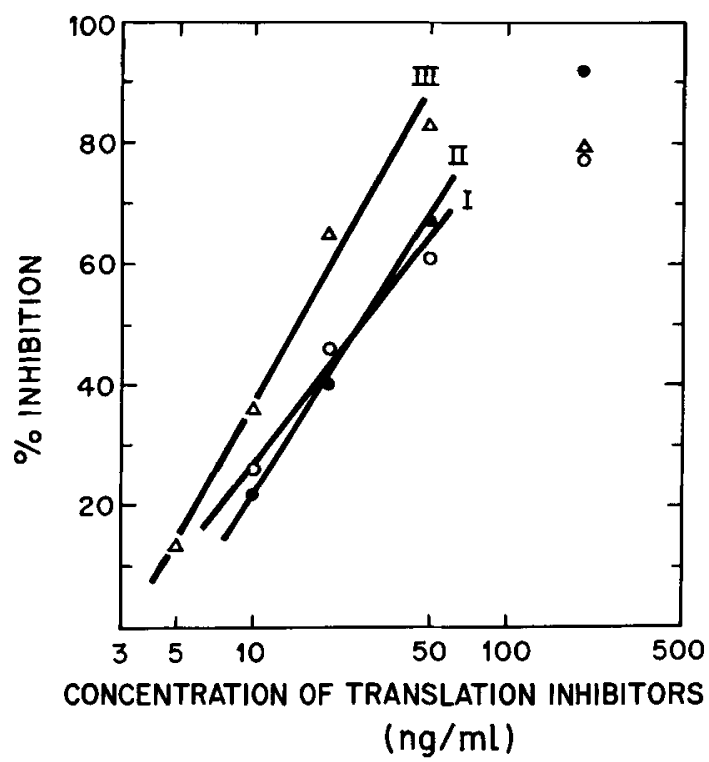

Figure 5. Inhibitory activities of the three translation inhibitors in the rabbit reticulocyte lysate system. Increasing amounts of translation inhibitors I (O), II $(\bullet)$ and III $(\Delta)$ were added to the rabbit reticulocyte lysate system and assayed for the in vitro translation as described in section 2.3.

similar type of inhibitor, $\alpha$-sarcin, produced by the mold Aspergillus giganteus, has been demonstrated to catalyze the specific cleavage of a single phosphodiester bond in intact ribosomal RNA and also to hydrolyze denatured ribosomal RNA and homopolynucleotides $(7,30)$. The translation inhibitors from barley were therefore examined for ribonuclease activity using as substrates rabbit liver ribosomal RNA and poly(A), $\operatorname{poly}(\mathrm{G})$, poly(C) and poly(U). The results, however, showed that the three inhibitors did not have any. detectable ribonuclease activity, in accordance with the findings for other translation inhibitors from plants $(29,32,33)$. This suggests that the mode of inhibition of the translation inhibitors from barley is different from that of $\alpha$-sarcin.

Further studies are in progress to elucidate the structure and the mechanism for the inhibition of protein synthesis by the barley translation inhibitors.

\section{ACKNOWLEDGEMENTS}

We are indebted to Professor MARTIN OTTE-
SEN for his continuous encouragement and advice during this work and for his critical revision of the manuscript. We are most grateful to Dr. ANDERS BRANDT for providing the wheat germ extract and for valuable discussions and help with the in vitro translation assay and polysome preparation. Dr. Poul SigSGaARD is thanked for providing the fresh rabbit liver. Drs. IB SVENDSEN and JOHN MUNDY are thanked for useful discussions. Mr. THORKILD BEENFELDT, Mss. SusSI DOHN, BODIL CORNELIUSSEn, LONE SøRENSEN and Pia BREddaM are acknowledged for excellent technical assistance. K. ASANO is on leave from Kirin Brewery Co., Ltd., Tokyo, Japan and acknowledges their financial support.

\section{REFERENCES}

1. Balestrieri, C., G. Colonna, A. Giovane, G. IRACE \& L. SER VILLO: Second-derivative spectroscopy of proteins. Eur. J. Biochem. 90, 433-440 (1978)

2. Barbieri, L., G.M. Aron, J.D. Irvin \& F, StirPe: Purification and partial characterization of another form of the antiviral protein from the seeds of Phytolacca americana L. (pokeweed). Biochem. J. 203, 55-59 (1982)

3. BRANDT, A.\& J. INGVERSEN: Isolation and translation of hordein messenger RNA from wild type and mutant endosperms in barley. Carlsberg Res. Commun. 43, $451-469$ (1978)

4. Coleman, W.H. \& W.K. ROBERTS: Inhibitors of animal cell-free protein synthesis from grains. Biochim. Biophys. Acta 696, 239-244 (1982)

5. DALlAL, J.A.\& J.D. IRVIN: Enzymatic inactivation of eukaryotic ribosomes by the pokeweed antiviral protein. FEBS Letters 89, 257-259 (1978)

6. Dubois, M., K.A. Gilles, J.K. Hamilton, P.A. REBERS \& F. SMITH: Colorimetric method for determination of sugars and related substances. Anal. Chem. 28, 350-356 (1956)

7. ENDO, Y. \& I.G. WOOL: The site of action of $\alpha$-sarcin on eukaryotic ribosomes. The sequence at the $\alpha$-sarcin cleavage site in $28 \mathrm{~S}$ ribosomal ribonucleic acid. J. Biol. Chem. 257, 9054-9060 (1982)

8. ENDO, Y., P.W. HuBer \& I.G. WoOL: The ribonuclease activity of the cytotoxin $\alpha$-sarcin. The characteristics of the enzymatic activity of $\alpha$-sarcin with ribosomes and ribonucleic acids as substrates. J. Biol. Chem. 258, 2662-2667 (1983)

9. Falasca, A., A. Gasperi-Campani, A. AbBonDANZA, L. BARBIERI \& F. STIRPE: Properties of the 
ribosome-inactivating proteins gelonin, Momordica charantia inhibitor, and dianthins. Biochem. J. 207, 505-509 (1982)

10. Friedman, M., J.C. Zahnley \& J.R. WAGNeR: Estimation of the disulfide content of trypsin inhibitors as S- $\beta$-(2-pyridylethyl)-L-cystein. Anal. Biochem. 106, 27-34 (1980)

11. Funatsu, G., S. Yoshitake \& M. Funatsu: Primary structure of Ile chain of ricin D. Agric. Biol. Chem. 42, 501-503 (1978)

12. Gasperi-Campani, A., L. Barbieri, E. LorenZONI\& F. STIRPE: Inhibition of protein synthesis by seed-extracts. FEBS Letters 76, 173-176 (1977)

13. Gasperi-CaMpani, A., L. Barbieri, P. MoRelli \& F. STIRPE: Seed extracts inhibiting protein synthesis in vitro. Biochem. J. 186, 439-441 (1980)

14. Hewlett, M.J., S. Rozenblatt, V. Ambros \& D. BALTIMORE: Separation and quantitation of intracellular forms of poliovirus RNA by agarose gel electrophoresis. Biochemistry 16, 2763-2767 (1977)

15. HiRS, C.H.W.: Determination of cystine as cysteic acid. Meth. Enzymol. 11, 59-62 (1967)

16. HoPP, H.E., S.K. RASMUSSEN \& A. BRANDT: Organization and transcription of $B 1$ hordein genes in high lysine mutants barley. Carlsberg Res. Commun. 48, 201-216 (1983)

17. Houston, L.L., S. Ramakrishnan \& M.A. Her. MODSON: Seasonal variations in different forms of pokeweed antiviral protein, a potent inactivator of ribosomes. J. Biol. Chem. 258, 9601-9604 (1983)

18. IRVIN, J.D., T. Kelly \& J.D. ROBERTUS: Purification and properties of a second antiviral protein from Phytolacca americana which inactivates eukaryotic ribosomes. Arch. Biochem. Biophys. 200, 418-425 (1980)

19. Isoelectric focusing. Principles \& methods. Pharmacia Fine Chemicals, Uppsala, Sweden

20. Johansen, J.T., C. Overballe-Petersen, B. MaRTin, V. Hasemann \& I. SvendSEN: The complete amino acid sequence of copper, zinc superoxide dismutase from Saccharomyces cerevisiae. Carlsberg Res. Commun. 44, 201-217 (1979)

21. Kumagai, H., K. Igarashi, T. Takayama, K Watanabe, K. Sugimoto \& S. Hirose: A mictosomal endoribonuclease from rat liver. Biochim. Biophys. Acta 608, 324-331 (1980)

22. LAEMMLI, U.K.: Cleavage of structural proteins during the assembly of the head of bacteriophage T4. Nature 227, 680-685 (1970)

23. LAURELL, C.B.: Quantitative estimation of proteins by electrophoresis in agarose gel containing antibodies. Anal. Biochem. 15, 59-62 (1967)

24. LIU, T.-Y. \& Y.H. ChanG: Hydrolysis of proteins with p-toluenesulfonic acid. Determination of tryptophan. J. Biol. Chem. 246, 2842-2848 (1971)

25. Mitchell, S.J., M. Hedblom, D. CAwley \& L.L. HONSTON: Ricin does not act as an endonuclease on $\mathrm{L}$ cell polysomal RNA. Biochem. Biophys. Res. Commun. 68, 763-769 (1976)

26. OLSNES, S.: Binding, entry, and action of abrin, ricin and modeccin. In: Transport of Macromolecules in Cellular System. S.C. Silverstein ed., Dahlem Konferenzen, Berlin pp. 103-116 (1978)

27. Olsnes, S., T. Haylett \& K. Refsnes: Purification and characterization of the highly toxic lectin modeccin. J. Biol. Chem. 253, 5069-5073 (1978)

28. ReisBig, R.P. \& O. Bruland: The protein synthesis inhibitors from wheat, barley and rye have identical antigenic determinants. Biochem. Biophys. Res. Commun. 114, 190-196 (1983)

29. ROBERTS, W.K. \& T.S. STEWART: Purification and properties of a translation inhibitor from wheat germ. Biochemistry 18, 2615-2621 (1979)

30. SCHINDLER, D.G. \& J.E. DAVIES: Specific cleavage of ribosomal RNA caused by alpha sarcin. Nucleic Acid Res. 4, 1097-1110 (1977)

31. Servillo, L., G. Colenna, C. Balestrieri, R. RAGORE\& G. IRACE: Simultaneous determination of tyrosine and tryptophan residues in proteins by second-derivative spectroscopy. Anal. Biochem. 126, 251-257 (1982)

32. Stirpe, F., A.Gasperi-Campani, L. Montanalo, S. SPERTI \& E. BONETTI: Inhibition of protein synthesis by modeccin, the toxin of Modecca digitata. FEBS Letters 85, 65-67 (1978)

33. Stirpe, F., A. Gasperi-CAMPani. L. Barnieri, A. Falasca, A. Abbondanza \& W.A. Stevens: Ribosome-inactivating proteins from the seeds of Saponaria officinalis L. (soapwort), of Agrostemma githago L. (corn cockle) and of Asparagus officinalis $L$. (asparagus), and from the latex of Hura crepirtans L. (sandbox tree). Biochem. J. 216, 617-625 (1983)

34. Svendsen, I., B. Martin \& I. Jonassen: Characteristics of Hiproly barley III. Amino acid sequences of two lysine-rich proteins. Carlsberg Res. Commun. 45, 79-85 (1980)

35. Svensson, B., K. LaRsen \& I. Svendsen: Amino acid sequence of tryptic fragments of glucoamylase G1 from Aspergillus niger. Carlsberg Res. Commun. 48, 517-527 (1983)

36. Wettstein, F.O., T. Staehelin \& H. Noll: Ribosomal aggregate engaged in protein synthesis. Characterization of the ergosome. Nature 197, 430-435 (1963)

Accepted by:

H. KLENOW, E. LUND and S.O. ANDERSEN 